\title{
Malignant pancreatic serous cystic neoplasms: systematic review with a new case
}

Jimi Huh ${ }^{1,2}$, Jae Ho Byun ${ }^{1 *}$, Seung-Mo Hong ${ }^{3}$, Kyung Won Kim ${ }^{1}$, jin Hee Kim', Seung Soo Lee ${ }^{1}$, Hyoung Jung $\mathrm{Kim}^{1}$ and Moon-Gyu Lee ${ }^{1}$

\begin{abstract}
Background: This study analyzes the clinicopathologic and radiologic characteristics of malignant serous cystic neoplasm (SCN) of the pancreas through systematic review and an institutional case report.

Methods: A comprehensive literature search was performed in the MEDLINE database to identify studies on malignant SCNs of the pancreas that had detailed clinicopathologic and radiologic information. A computerized systematic search of our institutional database was also performed to identify cases of malignant SCN for addition to the systematic review. Using the final included cases, we analyzed the clinicopathologic and radiologic features of malignant SCNs of the pancreas.

Results: A review of 136 candidate articles identified 26 studies with 26 cases that had detailed clinical information. Our institutional data search added one case. The systematic review of the 27 cases revealed that primary tumors (mean diameter $10.2 \pm 4.0 \mathrm{~cm}$ ) mainly involved the body and tail of the pancreas $(n=16)$ and frequently invaded adjacent organs $(n=19)$. Distant metastases occurred in 14 patients (synchronous, $n=5$; metachronous, $n=8$; both, $n=1)$, most commonly in the liver $(n=13)$. Imaging features of malignant SCNs of the pancreas were identical to the benign counterpart, except local invasion or distant metastases. The prognosis was excellent in that 17 were alive at the time of writing with a median follow-up period of 2 years.
\end{abstract}

Conclusions: The malignant potential of SCNs of the pancreas should be considered in the diagnosis and management of patients with pancreatic SCNs.

Keywords: Serous cystadenocarcinoma, Serous cystic neoplasms, Pancreas, Computed tomography, Magnetic resonance imaging

Abbreviations: CT, Computed tomography; DP, Distal pancreatectomy; FDG, ${ }^{18}$ F-fludeoxyglucose; MR, Magnetic resonance; PAS, Periodic acid-schiff; PD, Pancreaticoduodenectomy; PET, Positron emission tomography; PPPD, Pylorus preserving pancreaticoduodenectomy; SCN, Serous cystic neoplasm; SI, Signal intensity; TP, Total pancreatectomy; WHO, World Health Organization

\footnotetext{
* Correspondence: jhbyun@amc.seoul.kr

${ }^{1}$ Department of Radiology and Research Institute of Radiology, University of

Ulsan College of Medicine, Asan Medical Center, 88 Olympic-Ro 43-Gil,

Songpa-Gu, Seoul 05505, Korea

Full list of author information is available at the end of the article
} 


\section{Background}

Serous cystic neoplasms (SCNs) of the pancreas are usually cystic epithelial neoplasms composed of cuboidal, glycogen-rich, epithelial cells that produce serous fluid [1].

Pancreatic SCNs represent approximately 10-16\% of all kinds of cystic pancreatic lesions [2-5]. Since Compagno et al. classified cystic neoplasms of the pancreas into serous and mucinous types in 1978 [6], SCNs were considered as a benign disease entity without risk of malignant transformation. This concept changed after George et al. reported the first case of a malignant SCN of the pancreas in 1989 [7]. Thereafter, the number of case reports or series of malignant $\mathrm{SCNs}$ of the pancreas increased [4, 8-31]. Thus, SCNs of the pancreas are not considered totally benign, but have an extremely low malignant potential. Regarding the incidence of malignant SCNs, the majority of literature reported less than $1 \%$, including the largest series which showed three serous cystadenocarcinomas from 2622 patients [32], even though a few literature reported $1-5 \%[5,18,33]$. Due to its very rare chance to be malignant, the vast majority of SCNs are safely observed without resection [34].

As a result of their extreme rarity, the characteristics of malignant SCNs of the pancreas were not well explored until the World Health Organization (WHO) classification published in 2010 established the definition of serous cystadenocarcinoma and described its characteristics [1]. In the 2010 WHO classification, malignancy is defined by the presence of distant metastases regardless of benign-looking histologic features. However, the WHO classification is still under debate as many studies have classified SCNs that invade surrounding organs as malignant SCNs even though there is no distant metastasis $[4,9,12,13,16,21,22,24,25,27,29,33]$. Therefore, in this article, we use the broad term 'malignant SCNs' to include either SCNs with distant metastasis or local invasion.

Despite the increasing number of cases of malignant SCNs, there has been no systematic review to summarize the variable presentations of malignant $\mathrm{SCNs}$ and to provide a perspective of this rare disease entity. Therefore, we performed a systematic review of the malignant SCNs of the pancreas with the addition of our single case.

\section{Methods}

\section{Systematic literature search}

A computerized search of the MEDLINE database was conducted to find relevant studies published prior to April 30, 2015. Studies were eligible for inclusion if they described the clinicopathologic features, imaging findings, treatment, and outcome of the cases with regard to malignant SCNs of the pancreas. Any type of publication including case reports or case series was eligible. The following search terms were used: (pancreas OR pancreatic) AND ("serous cystadenocarcinoma" OR "serous cystic neoplasm"). Our search did not set any restriction or filter. To expand the search, the bibliographies of articles that remained after the selection process were screened for other potentially suitable articles.

\section{Institutional data search and case presentation}

Our institutional review board approved the search of electronic medical records for this study. We performed a systematic computerized search of our institutional database (ABLE, Asan Medical Center) from January 1996 to April 2015 using the diagnostic codes of 'serous cystic neoplasm of the pancreas', 'serous cystadenoma of the pancreas', and 'serous cystadenocarcinoma of the pancreas'. Using these search terms, we identified 447 patients initially diagnosed with $\mathrm{SCN}$ of the pancreas. Among the 447 patients, only one case was confirmed as serous cystadenocarcinoma of the pancreas. We obtained an informed consent from the patient. We present the clinical course, pathologic findings, and imaging features of this case. We also included this case in the systematic review of malignant SCNs.

\section{Analysis of clinicopathologic and radiologic features}

For the malignant SCNs from the literature search and our institution, we analyzed their clinicopathologic features, patterns of metastasis and local invasion, treatment, and outcome. When imaging features of the primary tumors and/or metastatic tumors were available, we also analyzed these imaging findings.

\section{Results}

\section{Literature selection}

Our study selection process is shown in Fig. 1. The literature search in the MEDLINE database generated 136 initial candidate articles. After reviewing the titles and the abstracts and excluding 22 review articles, two conference abstracts, and 80 articles that were not in the field of interest for this study, 32 articles were initially selected for eligibility. The full text of the 32 articles was retrieved. The search of the bibliographies of these articles found four additional eligible studies. Among these 36 eligible studies with 42 cases, we further excluded three articles that were not in the field of interest and seven studies that did not have detailed information on pancreatic serous cystadenocarcinomas, and selected 26 studies with 26 cases [4, 7-31]. We also included the present case from our institution; thus finally 27 cases were reviewed in this systematic review.

\section{Presentation of our case}

A 52-year-old woman presented to our institution with a palpable abdominal mass. On physical examination, a 


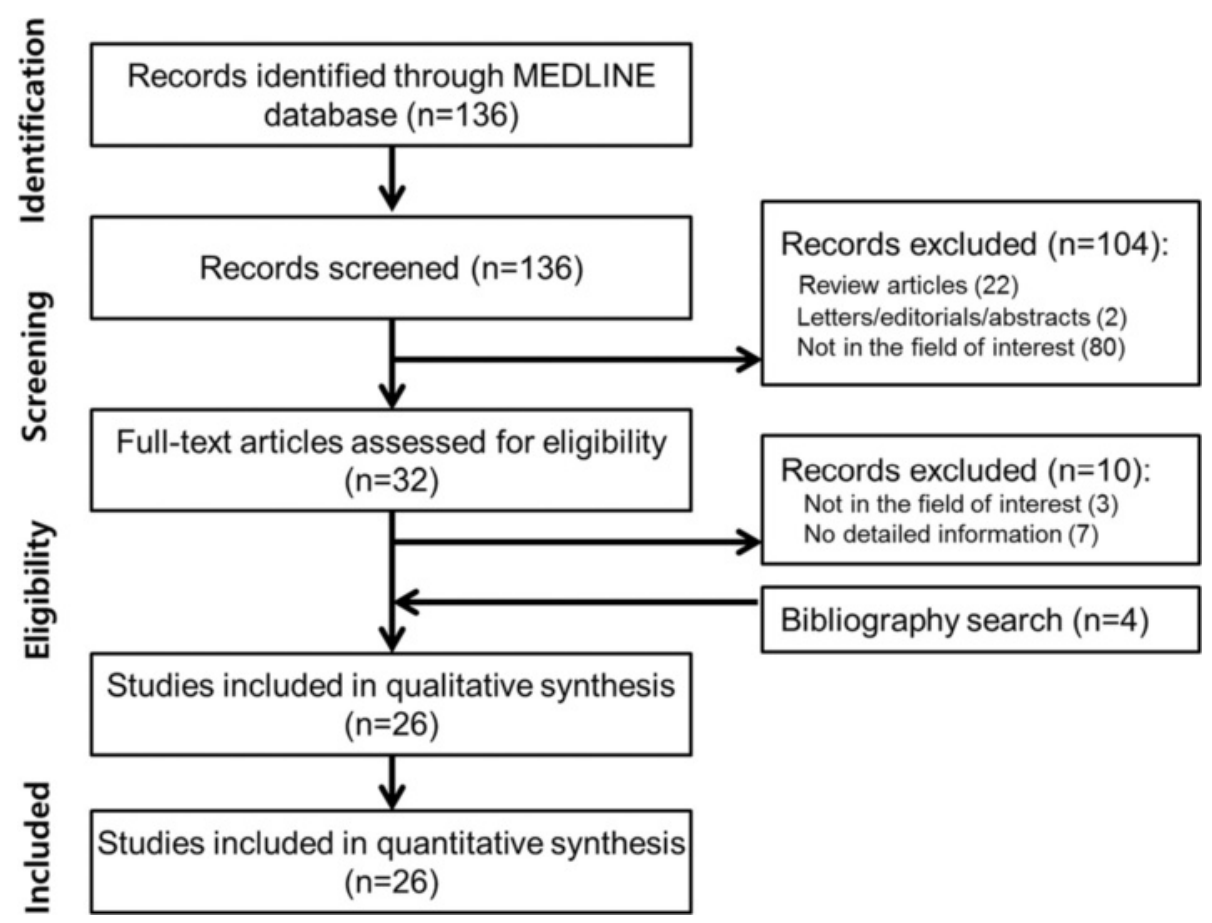

Fig. 1 Flow diagram for literature selection

large, soft mass was palpable in the epigastrium. Results of laboratory examinations and tumor markers (carcinoembryonic antigen and carbohydrate antigen 19-9) were within the normal range. Serum chromogranin A was $108 \mathrm{ng} / \mathrm{mL}$, which was around the upper normal limit (27-94 $\mathrm{ng} / \mathrm{mL})$. Contrast-enhanced computed tomography (CT) scans showed a $9 \times 8 \mathrm{~cm}$ solid and cystic mass in the head of the pancreas (Fig. 2a). The peripheral portion of the tumor was well enhanced, while the central portion was not well enhanced. On ${ }^{18} \mathrm{~F}$ fludeoxyglucose (FDG) positron emission tomography $(\mathrm{PET}) / \mathrm{CT}$ scans, the tumor did not show any increased uptake (Fig. 2b).

Pancreaticoduodenectomy was performed with a clinical diagnosis of a solid pseudopapillary neoplasm or pancreatic neuroendocrine tumor. On the gross specimen, a well-demarcated lobulated mass was observed in the pancreas head. The cut surface showed a yellowish, gray, firm tumor with multiple microcystic changes and fibrous septa (Fig. 2c). Vascular and perivascular invasions and nodal involvement were not observed. Microscopic findings revealed multiple microcysts separated by collagen fibers. The inner surface of the cysts was lined by a single layer of cuboidal epithelium with a clear cytoplasm (Fig. 2d). No mitoses or cellular atypia were noted. Immunohistochemical staining was positive for the cytokeratins, AE1 and AE3, and negative for CD56, chromogranin A, synaptophysin, renal cell carcinoma marker, and CD10. The epithelial cells of the tumor had cytoplasmic periodic acid-Schiff (PAS)-positive granules. The histopathological diagnosis was serous cystadenoma of the pancreas.

Five years later, the patient presented with abdominal discomfort. On contrast-enhanced CT, there were multiple liver masses/nodules that showed peripheral rim enhancement (Fig. 2e). Under suspicion of liver metastases, FDG-PET scanning was performed, which revealed no FDG avidity in any liver masses/nodules. There was no evidence of local tumor recurrence or extrahepatic metastasis on FDG-PET/CT scans and body CT. The tumor showed very high signal intensity (SI) like cerebrospinal fluid on T2-weighted magnetic resonance (MR) image (Fig. 2f) and low SI on T1-weighted image. On diffusion-weighted images and apparent diffusion coefficient map, there was no diffusion restriction in the tumor. On multiphasic contrast-enhanced T1-weighted MR images, the tumor showed peripheral rim enhancement in the arterial phase, portal-venous phase, and delayed phase (Fig. 2g).

Ultrasound-guided biopsy was performed for the liver masses. Pathologic results showed that the tumor specimen was composed of multiple microcysts separated by collagen fibers (Fig. 2h). The microcysts were lined by a single layer of cuboidal epithelium with a clear cytoplasm and bland-looking nuclei. These histopathologic features were very similar to those of the previous 

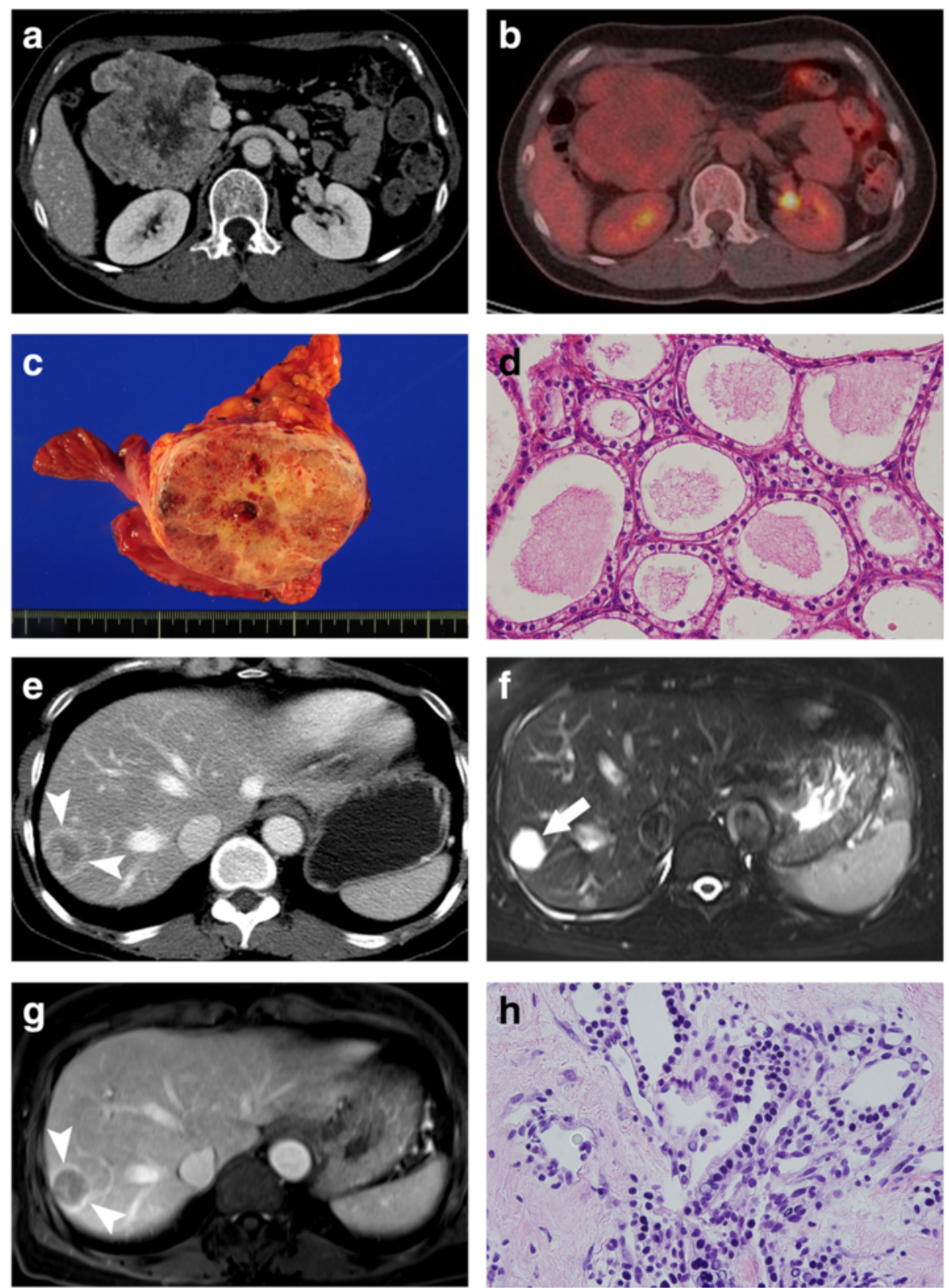

Fig. 2 A 52-year-old woman with malignant serous cystic neoplasm of the pancreas and metachronous hepatic metastasis. a Contrast-enhanced CT scan demonstrates a $9 \times 8 \mathrm{~cm}$ solid and cystic mass in the pancreatic head. $\mathbf{b}$ FDG-PET/CT scan demonstrates no increased uptake within the tumor. c Photograph of the gross specimen shows a well-demarcated lobulated mass. The cut surface showed a yellowish, gray, firm tumor with multiple microcystic changes and fibrous septa. $\mathbf{d}$ Photomicrograph shows multiple microcysts lined by a single layer of cuboidal epithelium with a clear cytoplasm ( $H$ and E stain, $\times 200$ ). e Contrast-enhanced $C T$ scan shows a low-attenuating nodular lesion with peripheral rim enhancement in liver segment VII. f On T2-weighted MR image, the liver tumor shows very bright signal intensity like cerebrospinal fluid. $\mathbf{g}$ On contrast-enhanced T1-weighted MR image during the portal-venous phase, the tumor shows peripheral rim enhancement. $\mathbf{h}$ Photomicrograph shows that the tumor is composed of multiple microcysts separated by collagen fibers, which are lined by a single layer of cuboidal epithelium with a clear cytoplasm and bland-looking nuclei $(\mathrm{H}$ and $\mathrm{E}$ stain, $\times 200$ )

pancreaticoduodenectomy specimen. Finally, the histologic diagnosis was confirmed as serous cystadenocarcinoma with metachronous liver metastasis.

The patient has been observed without any treatment for the liver metastases for 17 months after liver mass biopsy. The liver metastases have minimally enlarged on follow-up CT as the largest liver metastasis has increased from 3.1 to $3.4 \mathrm{~cm}$ in the longest diameter over 17 months. However, the patient has been asymptomatic and is still alive at the time of writing. 


\section{Systematic review}

The characteristics of the 27 included cases of malignant SCNs are summarized in Table 1 . The 27 cases were diagnosed as malignant SCNs of the pancreas because they exhibited characteristics of malignancy including local invasion and/or distant metastasis. According to the definition of the 2010 WHO classification, which defines pancreatic serous cystadenocarcinoma by the presence of distant metastases, only 14 cases were pancreatic serous cystadenocarcinoma. However, we also analyzed the cases with local invasion.

\section{Clinical features}

The mean age of patients with malignant SCNs was 68.0 \pm 10.4 years with a range of $42-87$ years. The female to male ratio was 2.9 (20 females and seven males). Regarding the presenting symptoms or signs, abdominal/flank pain was the most commonly presented ( $n=13 ; 48.1 \%)$, followed by a palpable mass $(n=6 ; 22.2 \%)$, weight loss $(n$ $=5 ; 18.5 \%)$, gastrointestinal bleeding $(n=3 ; 11.1 \%)$, incidental detection $(n=3 ; 11.1 \%)$, and jaundice or abnormal levels of serum liver enzymes $(n=3 ; 11.1 \%)$.

\section{Morphologic and radiologic features}

On gross specimens, the most common pattern was the microcystic type $(n=20)$, which is defined as multiple cysts measuring $<2 \mathrm{~cm}$ separated by thin fibrous septa. The macrocystic type, which is composed of large cysts $\geq 2 \mathrm{~cm}$, was observed in two cases. The mixed microcystic and macrocystic type was found in two cases. There was only one case with the solid type. In two articles, there was no information on the gross morphological type of SCN.

CT or MR imaging features were available in 20 cases, in which the imaging features of the primary tumors and/or metastatic lesions were qualitatively described. In all cases, the imaging findings of the malignant SCNs of the pancreas were basically identical to those of benign serous cystadenoma, except for malignant behavior such as local invasion or distant metastases. The radiologic features of serous cystadenoma or cystadenocarcinoma generally varied according to the gross morphologic pattern. Tumors with the microcystic pattern were generally shown as well-circumscribed, multilocular masses, with or without central stellate scars. The microcysts were not clearly identified on $\mathrm{CT}$, but were very hyperintense on T2-weighted MR images. Tumors with the macrocystic pattern were shown as well-circumscribed, lobulated masses containing a few cysts. The SCNs with a mixed microcystic and macrocystic type simultaneously showed findings of the micro- and macrocystic types. The solid type of malignant SCN reported in one case was shown as a solid enhancing mass that initially mimicked a neuroendocrine tumor.
Regarding the malignant features, local invasion to the adjacent vessels, spleen, liver, adrenal glands, stomach, or colon could be detected on $\mathrm{CT}$ and/or MR images. Among the 27 cases with malignant SCNs, 13 had hepatic metastasis. Seven of thirteen cases described enhancement patterns and morphological characteristics of the liver metastasis. Six synchronous or metachronous metastases in the liver were cystic masses with peripheral enhancement on contrastenhanced CT/MRI and showed very high SI on T2weighted images. Only one hepatic metastatic mass showed heterogeneous wall enhancement; however, it also demonstrated very high SI on T2-weighted images like the other masses. Taking all into account, the liver metastases, which are basically cystic masses, can be characterized as exhibiting very high SI on T2weighted images, with an enhancing cyst wall and/or fibrous septa.

\section{Primary tumors and local invasion}

The mean diameter of the primary pancreatic tumors was $10.2 \pm 4.0 \mathrm{~cm}$ (range, 2.5-19 cm). The locations of the primary tumors were as follows: pancreatic head ( $n=7 ; 25.9 \%)$, pancreatic body and tail $(n=9 ; 33.3 \%)$, pancreatic body $(n=5 ; 18.5 \%)$, pancreatic tail $(n=2$; $7.4 \%)$, entire pancreas $(n=3 ; 11.1 \%)$, or location unavailable $(n=1 ; 3.7 \%)$.

Local invasion of the adjacent organs occurred in 19 patients $(70.4 \%)$ including six patients with invasion of multiple organs, as follows: adjacent vessels $(n=7 ; 25.9 \%)$, spleen $(n=5 ; 18.5 \%)$, peripancreatic fat $(n=3 ; 11.1 \%)$, stomach $(n=3 ; 11.1 \%)$, duodenum $(n=3 ; 11.1 \%)$, colon $(n=1 ; 3.7 \%)$, liver $(n=1 ; 3.7 \%)$, retroperitoneum $(n=1$; $3.7 \%)$, and perineural invasion $(n=1 ; 3.7 \%)$.

\section{Metastasis patterns}

Among the 27 cases with malignant SCNs, 14 had a distant metastasis: synchronous metastases in five patients (18.5\%), metachronous metastases in eight patients (32\%), and both synchronous and metachronous metastases in one patient $(3.7 \%)$. The time interval between detection of pancreatic SCN and metachronous metastases was from 1 to 10 years (median, 3 years).

Among the 14 patients with distant metastases, including two patients with metastasis in multiple organs, the sites of distant metastases were as follows: liver $(n=13$; $92.9 \%)$, lung ( $n=1 ; 7.1 \%)$, bone $(n=1 ; 7.1 \%)$, adrenal glands $(n=1 ; 7.1 \%)$, peritoneum $(n=1 ; 7.1 \%)$, and spleen $(n=1 ; 7.1 \%)$. Notably, liver metastasis was found in all patients with metachronous metastases. Among the 27 patients, only four patients had lymph node metastases; however, the exact site of lymph node metastasis was unavailable. 
Table 1 Characteristics of included cases of malignant serous cystic neoplasms of the pancreas

\begin{tabular}{|c|c|c|c|c|c|c|c|c|c|c|c|c|}
\hline Author & Year & Age & Sex & Signs or symptoms & Location & $\begin{array}{l}\text { Tumor } \\
\text { diameter } \\
\text { (cm) }\end{array}$ & $\begin{array}{l}\text { Gross } \\
\text { morphologic } \\
\text { patten }\end{array}$ & $\begin{array}{l}\text { Distant } \\
\text { metastatic } \\
\text { sites }\end{array}$ & $\begin{array}{l}\text { Synchronous/ } \\
\text { Metachronous }^{\mathrm{a}}\end{array}$ & $\begin{array}{l}\text { Local invasion } \\
\text { sites }\end{array}$ & Surgical therapy & Outcome \\
\hline $\begin{array}{l}\text { George } \\
\text { et al }\end{array}$ & 1989 & 70 & M & $\begin{array}{l}\text { Hemorrhage from } \\
\text { gastric varices }\end{array}$ & $\begin{array}{l}\text { body and } \\
\text { tail }\end{array}$ & 11 & Micorocystic & Liver & Synchronous & $\begin{array}{l}\text { Stomach, } \\
\text { spleen, splenic } \\
\text { vein }\end{array}$ & DP & $\begin{array}{l}\text { Death during } \\
\text { operation due to } \\
\text { hemorrhage }\end{array}$ \\
\hline $\begin{array}{l}\text { Friedman } \\
\text { et al. }\end{array}$ & 1990 & 74 & $F$ & $\begin{array}{l}\text { Right flank pain, } \\
\text { weight loss, palpable } \\
\text { mass }\end{array}$ & head & 19 & Macrocystic & $\begin{array}{l}\text { Liver, lung, } \\
\text { bone, } \\
\text { adrenal } \\
\text { glands }\end{array}$ & Synchronous & None & None & $\begin{array}{l}\text { Death due to } \\
\text { advanced neoplasm }\end{array}$ \\
\hline Kamei et al. & 1991 & 72 & $F$ & Jaundice & $\begin{array}{l}\text { Multifocal } \\
\text { origin } \\
\text { (head, } \\
\text { body,tail) }\end{array}$ & 10 & Microcystic & & & Neural invasion & TP & NA \\
\hline Okada et al. & 1991 & 63 & $\mathrm{~F}$ & Abdominal pain & $\begin{array}{l}\text { body and } \\
\text { tail }\end{array}$ & 12 & Microcystic & Liver & $\begin{array}{l}\text { Metachronous } \\
\text { (4 years) }\end{array}$ & None & DP & $\begin{array}{l}\text { Alive } 5 \text { years after } \\
\text { initial operation }\end{array}$ \\
\hline $\begin{array}{l}\text { Yoshimi } \\
\text { et al. }\end{array}$ & 1992 & 63 & $\mathrm{~F}$ & $\begin{array}{l}\text { Epigastric pain, } \\
\text { palpable mass }\end{array}$ & $\begin{array}{l}\text { body and } \\
\text { tail }\end{array}$ & 12 & Microcystic & Liver & $\begin{array}{l}\text { Metachronous } \\
\text { (3 years) }\end{array}$ & None & DP & $\begin{array}{l}\text { Alive } 6 \text { years after } \\
\text { initial operation }\end{array}$ \\
\hline Ohta et al. & 1993 & 64 & M & $\begin{array}{l}\text { Unrelated incidental } \\
\text { detection of the tumor } \\
\text { on abdominal CT }\end{array}$ & body & 2.5 & Microcystic & & & $\begin{array}{l}\text { Perivascular and } \\
\text { vascular } \\
\text { invasion }\end{array}$ & Enucleation & $\begin{array}{l}\text { Alive } 9 \text { months after } \\
\text { initial operation }\end{array}$ \\
\hline $\begin{array}{l}\text { Widmaier } \\
\text { et al }\end{array}$ & 1996 & 71 & M & $\begin{array}{l}\text { Elevated liver function } \\
\text { tests }\end{array}$ & head & 4 & Mixed & & & $\begin{array}{l}\text { Peripancreatic } \\
\text { fat }\end{array}$ & PPPD & Alive 1 year later \\
\hline $\begin{array}{l}\text { Ishikawa } \\
\text { et al. }\end{array}$ & 1998 & 63 & $F$ & Abdominal pain & body & 12 & Microcystic & Liver & $\begin{array}{l}\text { Metachronous } \\
\text { ( } 3 \text { years) }\end{array}$ & None & DP & NA \\
\hline $\begin{array}{l}\text { Eriguchi } \\
\text { et al. }\end{array}$ & 1998 & 65 & $\mathrm{~F}$ & $\begin{array}{l}\text { Palpable abdominal } \\
\text { mass }\end{array}$ & $\begin{array}{l}\text { body and } \\
\text { tail }\end{array}$ & 16 & Microcystic & Liver & Both (9 years) & None & $\begin{array}{l}\text { DP, micorowave coagulo- } \\
\text { necrotic therapy }\end{array}$ & $\begin{array}{l}\text { Alive } 10 \text { year after } \\
\text { initial operation }\end{array}$ \\
\hline Abe et al. & 1998 & 71 & $F$ & $\begin{array}{l}\text { Palpable abdominal } \\
\text { mass, general fatigue, } \\
\text { weight loss }\end{array}$ & $\begin{array}{l}\text { body and } \\
\text { tail }\end{array}$ & 12 & Microcystic & & & $\begin{array}{l}\text { Lymph node, } \\
\text { peripancreatic } \\
\text { fat }\end{array}$ & DP, splenectomy & Alive 2 years later \\
\hline $\begin{array}{l}\text { Horvath } \\
\text { et al. }\end{array}$ & 1999 & 81 & $\mathrm{~F}$ & NA & NA & 6 & NA & & & Vessel & DP & NA \\
\hline Wu et al. & 1999 & 57 & $\mathrm{~F}$ & $\begin{array}{l}\text { Unrelated, incidental } \\
\text { detection of the tumor } \\
\text { on abdominal } C T\end{array}$ & $\begin{array}{l}\text { entire } \\
\text { pancreas }\end{array}$ & 5.5 & Mixed & $\begin{array}{l}\text { Liver, } \\
\text { peritoneum }\end{array}$ & $\begin{array}{l}\text { Metachronous } \\
\text { (10 year) }\end{array}$ & Stomach & $\begin{array}{l}\text { Pancreatectomy, } \\
\text { splenectomy, } \\
\text { cholecystectomy }\end{array}$ & $\begin{array}{l}\text { Recurrence } 10 \text { years } \\
\text { after initial tumor } \\
\text { resection }\end{array}$ \\
\hline $\begin{array}{l}\text { Strobel } \\
\text { et al. }\end{array}$ & 2001 & 56 & $F$ & $\begin{array}{l}\text { Recurrent abdominal } \\
\text { pain, diarrhea, weight } \\
\text { loss }\end{array}$ & $\begin{array}{l}\text { entire } \\
\text { pancreas }\end{array}$ & 14 & Microcystic & Liver & $\begin{array}{l}\text { Metachronous } \\
\text { (3 years) }\end{array}$ & None & PPPD & $\begin{array}{l}\text { Alive } 3 \text { years after } \\
\text { initial operation }\end{array}$ \\
\hline $\begin{array}{l}\text { Matsumoto } \\
\text { et al. }\end{array}$ & 2004 & 87 & $\mathrm{~F}$ & $\begin{array}{l}\text { no symptom, } \\
\text { incidental } \\
\text { finding(inguinal hernia } \\
\text { op) }\end{array}$ & $\begin{array}{l}\text { body and } \\
\text { tail }\end{array}$ & 12 & Microcystic & Spleen & Synchronous & Spleen, Vessel & DP with colectomy & $\begin{array}{l}\text { Uneventful } \\
\text { (10 months) }\end{array}$ \\
\hline $\begin{array}{l}\text { Schintaku } \\
\text { et al. }\end{array}$ & 2005 & 85 & $F$ & $\begin{array}{l}\text { Fatigue, intermittent } \\
\text { diarrhea }\end{array}$ & $\begin{array}{l}\text { body and } \\
\text { tail }\end{array}$ & 12 & Microcystic & & & Spleen & DP, distal gastrectomy & Alive 10 months later \\
\hline
\end{tabular}


Table 1 Characteristics of included cases of malignant serous cystic neoplasms of the pancreas (Continued)

\begin{tabular}{|c|c|c|c|c|c|c|c|c|c|c|c|c|}
\hline Friebe et al. & 2005 & 80 & $\mathrm{~F}$ & $\begin{array}{l}\text { Abdominal pain, } \\
\text { anorexia, weight loss }\end{array}$ & $\begin{array}{l}\text { body and } \\
\text { tail }\end{array}$ & 8 & Microcystic & & & Spleen & DP, splenectomy & Alive 1 year later \\
\hline Gupta et al. & 2008 & 42 & $\mathrm{~F}$ & $\begin{array}{l}\text { Abdominal pain, } \\
\text { palpable abdominal } \\
\text { mass, diarrhea, weight } \\
\text { loss }\end{array}$ & $\begin{array}{l}\text { body and } \\
\text { tail }\end{array}$ & 10 & Macrocystic & & & $\begin{array}{l}\text { peripancreatic } \\
\text { fat. }\end{array}$ & DP, splenectomy & Alive 2 years later \\
\hline Franko et al. & 2008 & 68 & $\mathrm{~F}$ & $\begin{array}{l}\text { Flank pain, weight loss, } \\
\text { anemia, duodenal } \\
\text { bleeding }\end{array}$ & head & 5 & Microcystic & Liver & $\begin{array}{l}\text { Metachronous } \\
\text { (3 years) }\end{array}$ & $\begin{array}{l}\text { Splenoportal } \\
\text { vein, } \\
\text { duodenum }\end{array}$ & Inoperable & $\begin{array}{l}\text { Death due to } \\
\text { advanced neoplasm, } \\
45 \text { months later }\end{array}$ \\
\hline King et al. & 2009 & 70 & M & $\begin{array}{l}\text { Abdominal pain, } \\
\text { hematemesis }\end{array}$ & head & 9 & Microcystic & & & Duodenum & PPPD & Alive 7 years later \\
\hline Vadala et al. & 2010 & 74 & M & NA & head & NA & NA & & & Portal vein & $\begin{array}{l}\text { PD, portal vein } \\
\text { thrombectomy }\end{array}$ & NA \\
\hline Bano et al. & 2011 & 62 & M & $\begin{array}{l}\text { Abdominal pain, } \\
\text { vomiting, weight loss, } \\
\text { jaundice }\end{array}$ & head & 7 & Microcystic & Liver & $\begin{array}{l}\text { Metachronous } \\
\text { (1 year) }\end{array}$ & Duodenum & $\begin{array}{l}\text { PD, microwave coagulo- } \\
\text { necrotic therapy }\end{array}$ & Alive 1 year later \\
\hline Cho et al. & 2011 & 64 & $\mathrm{~F}$ & $\begin{array}{l}\text { Dizziness, } \\
\text { hematochezia }\end{array}$ & tail & 12 & Microcystic & & & $\begin{array}{l}\text { Colon, spleen } \\
\text { invasion }\end{array}$ & $\begin{array}{l}\text { DP, segmental resection of } \\
\text { the colon, splenectomy }\end{array}$ & NA \\
\hline Bramis et al. & 2012 & 86 & $\mathrm{~F}$ & Abdominal pain & body & 17 & Microcystic & Liver & Synchronous & Stomach & Inoperable, Biopsies taken & $\begin{array}{l}\text { Died } 1 \text { month later } \\
\text { due to unrelated } \\
\text { other medical } \\
\text { problem }\end{array}$ \\
\hline $\begin{array}{l}\text { Wasel BA } \\
\text { et al. }\end{array}$ & 2013 & 68 & $\mathrm{~F}$ & Incidental finding & tail & 12 & Microcystic & & & $\begin{array}{l}\text { Liver, } \\
\text { retroperitoneum }\end{array}$ & $\begin{array}{l}\text { Inoperable, neo-adjuvant } \\
\text { chemotherapy }\end{array}$ & Alive 1 year later \\
\hline $\begin{array}{l}\text { Rathore MU } \\
\text { et al. }\end{array}$ & 2013 & 60 & $\mathrm{~F}$ & Upper abdominal pain & body & 9 & Microcystic & & & Vessels & $\begin{array}{l}\text { Partial pancreatectomy and } \\
\text { splenectomy }\end{array}$ & $\begin{array}{l}\text { Death 3rd post } \\
\text { operative day due to } \\
\text { thromboembolism }\end{array}$ \\
\hline $\begin{array}{l}\text { Kainuma O } \\
\text { et al. }\end{array}$ & 2015 & 69 & M & $\begin{array}{l}\text { Upper abdominal } \\
\text { discomfort }\end{array}$ & body & 6 & Solid variant & Liver & Synchronous & None & $\begin{array}{l}\text { Distal pancreatectomy(initial } \\
\text { diagnossi) }+ \text { Liver } \\
\text { metastatectomy( } 27 \text { months } \\
\text { later) }\end{array}$ & Alive 30 months later \\
\hline $\begin{array}{l}\text { Present } \\
\text { case }\end{array}$ & 2015 & 52 & $\mathrm{~F}$ & Palpable mass & head & 9 & Microcystic & Liver & $\begin{array}{l}\text { Metachronous } \\
\text { ( } 5 \text { years) }\end{array}$ & None & PD & Alive 6.5 years later \\
\hline
\end{tabular}

$D P$ distal pancreatectomy, TP total pancreatectomy, PD pancreaticoduodenectomy, PPPD pylorus preserving pancreaticoduodenectomy

a Number in parenthesis is time interval between detection of primary pancreatic tumor and metachronous metastasis 


\section{Treatment and outcome}

Regarding the treatment of primary tumors, surgical resection of the primary pancreatic SCN was performed in 23 patients $(85.2 \%)$. Three patients were inoperable due to local invasion $(n=2)$ and synchronous metastases $(n=1)$. In one case report focusing on histopathologic features, the treatment was not stated [8].

Among the 27 cases, death was reported in five patients only, which was due to either an advanced pancreatic neoplasm $(n=2)$, perioperative mortality $(n=2)$, or unrelated medical problem $(n=1)$. The two patients who died from advanced tumors had metastasis in various organs. Time to death ranged from 3 days to 45 months from the initial surgery or diagnosis. In 17 cases, patients were alive at the time of writing, with a median follow-up period of 2 years (range, 9 months to 10 years from the initial surgery or diagnosis). Patient outcomes were not reported for the other five patients.

\section{Discussion}

Our systematic review of malignant SCNs of the pancreas adds to growing evidence that SCNs of the pancreas have malignant potential. As a result of their rarity, radiologists and clinicians generally consider SCNs of the pancreas as benign. With the growing number of malignant SCNs, we need to establish diagnostic criteria for malignant $\mathrm{SCNs}$ of the pancreas. Regarding the primary tumors, malignant transformation into cystadenocarcinoma is suggested by an increase in size, heterogeneous morphological characteristics, and poor distinction from the surrounding pancreatic parenchyma [26]. Direct invasion of the adjacent organs and the presence of distant metastases are hallmarks of malignant SCNs of the pancreas. Although, the 2010 WHO classification defined malignancy by the presence of distant metastases regardless of benign-looking histologic features, the WHO classification is still under debate as many studies have classified SCNs that invade surrounding organs as malignant SCNs $[4,9,12,13,16,21,22,24,25,27,29,33]$. However, it is difficult to differentiate local invasion from mass effect in a large tumor, particularly on preoperative imaging studies. Particularly, it is more difficult to identify the presence of local invasion in patients with SCNs as SCN is a cystic tumor. Therefore, the definition of local invasion in SCNs on imaging studies should be more clearly established like that of vascular invasion in solid tumors. The vascular invasion in solid tumors is usually defined as an encasement of the vessel (greater than $180^{\circ}$ vascular circumferential involvement) or irregular narrowing of the vessel with involvement of vessel wall by the tumor [35].

Interestingly, in nine cases with metachronous distant metastasis, liver metastases occurred after complete resection of the primary tumor with the time interval ranging from 1 to 10 years. Therefore, follow-up imaging exams should include the liver. The liver metastases from serous cystadenocarcinoma are frequently cystic in nature with a similar histology to that of the primary pancreatic tumor. T2-weighted images might be the most important sequence for characterizing liver metastases. When new multiseptated cystic lesions are detected in the liver after resection of SCNs of the pancreas, the possibility of metachronous liver metastases should be considered.

Synchronous liver metastases occurred in five cases when the primary pancreatic SCNs were diagnosed. The imaging features of liver metastases were similar to those of primary pancreatic SCNs. Therefore, when multiseptated cystic lesions compatible with SCNs are found in the liver and pancreas, we should consider the possibility of pancreatic SCNs with synchronous liver metastases from the initial diagnostic step, despite its rarity. In these cases, a more vigorous diagnostic work-up is needed.

Regarding the outcome of those included studies, two died from perioperative mortality, one died from unrelated medical problem, and two died from advanced tumors. The other 17 patients were alive at the time of writing. These findings indicate that surgical resection should be decided very carefully due to high perioperative mortality and relatively indolent course of malignant SCNs. In current status, it is difficult to find predictive factors for death due to small number of death cases, warranting further evidence.

Nowadays, clinicians have a dilemma in the management of SCN of the pancreas [35]. In general, the current management of serous cystadenomas of the pancreas is essentially conservative. Indeed, the vast majority of cases do not need surveillance after initial diagnosis. Surgery is indicated in cases with new symptoms or complications such as abdominal pain, pancreatitis, and biliary obstruction [28]. Since the malignant potential in the pancreatic SCNs is very low, pancreatic SCNs can be safely observed without surgical resection in the vast majority of cases. However, due to its malignant potential, we need to establish certain criteria for the surveillance of SCN of the pancreas. A comprehensive panel of patient's symptoms/signs, imaging, cytopathology, tumor growth rate, and biological activity is essential for decision making. Thus, regular physical exam, serum tumor markers, imaging studies including CT or MRI, endoscopic ultrasonography, and cyst fluid analysis should be performed appropriately.

Our study has limitations. First, it is a systematic literature review, hence the data such as malignant imaging features or local invasion were extracted from individual studies. The presence of malignant imaging features or local invasion were determined based on the imaging description in individual studies. Second, all 
cases were gathered from different institutions where the clinical practice might vary, which may raise issue of heterogeneity of included cases. However, this is also an inevitable limitation of a systematic literature review.

\section{Conclusions}

In conclusion, the number of reported cases of malignant SCNs of the pancreas is growing, prompting radiologists and clinicians to redefine this disease entity and establish guidelines for diagnosis and management of malignant SCNs of the pancreas. A comprehensive panel of patient's symptoms/signs, imaging, cytopathology, tumor growth rate, and biological activity is essential to diagnose and manage malignant SCNs of the pancreas.

\section{Funding}

This work did not require any funding.

\section{Authors' contributions}

$\mathrm{JH}$ and $\mathrm{JHB}$ designed and conducted the study and drafted the manuscript. $\mathrm{JH}$ and KWK conducted literature search, data extraction, and data interpretation. SSL, JHK and HJK reviewed CT and MR imaging, interpreted the data and contributed to the discussion. SMH performed pathologic review. MGL supervised the study and contributed to the discussion, edited and approved the manuscript. All authors read, revised, and approved the manuscript.

\section{Competing interests}

All authors declare that they have no financial and non-financial competing interests.

\section{Ethics approval and consent to participate}

Our institutional review board approved the search of electronic medical records for this study. We obtained an informed consent for publication from the patient. All data generated or analysed during this study are included in this published article.

\section{Author details}

${ }^{1}$ Department of Radiology and Research Institute of Radiology, University of Ulsan College of Medicine, Asan Medical Center, 88 Olympic-Ro 43-Gil, Songpa-Gu, Seoul 05505, Korea. ${ }^{2}$ Department of Radiology, University of Ulsan College of Medicine, Ulsan University Hospital, 877

Bangeojinsunhwando-ro, Dong-gu, Ulsan 44033, Korea. ${ }^{3}$ Department of Pathology, University of Ulsan College of Medicine, Asan Medical Center, 88 Olympic-Ro 43-Gil, Songpa-Gu, Seoul 05505, Korea.

Received: 22 December 2015 Accepted: 11 August 2016 Published online: 22 August 2016

\section{References}

1. Bosman FT, Carneiro F, Hruban RH, Theise ND. WHO classification of tumours of the digestive system. Geneva: World Health Organization; 2010.

2. Valsangkar NP, Morales-Oyarvide V, Thayer SP, Ferrone CR, Wargo JA, Warshaw AL, Fernandez-del Castillo C. 851 resected cystic tumors of the pancreas: a 33-year experience at the Massachusetts General Hospital. Surgery. 2012;152(3 Suppl 1):S4-12.

3. Kosmahl M, Pauser U, Peters K, Sipos B, Luttges J, Kremer B, Kloppel G. Cystic neoplasms of the pancreas and tumor-like lesions with cystic features: a review of 418 cases and a classification proposal. Virchows Arch. 2004:445(2):168-78.

4. Horvath KD, Chabot JA. An aggressive resectional approach to cystic neoplasms of the pancreas. Am J Surg. 1999;178(4):269-74.

5. Galanis C, Zamani A, Cameron JL, Campbell KA, Lillemoe KD, Caparrelli D, Chang D, Hruban RH, Yeo CJ. Resected serous cystic neoplasms of the pancreas: a review of 158 patients with recommendations for treatment. J Gastrointest Surg. 2007;11(7):820-6.
6. Compagno J, Oertel JE. Microcystic adenomas of the pancreas (glycogenrich cystadenomas): a clinicopathologic study of 34 cases. Am J Clin Pathol. 1978;69(3):289-98.

7. George DH, Murphy F, Michalski R, Ulmer BG. Serous cystadenocarcinoma of the pancreas: a new entity? Am J Surg Pathol. 1989;13(1):61-6.

8. Friedman HD. Nonmucinous, glycogen-poor cystadenocarcinoma of the pancreas. Arch Pathol Lab Med. 1990;114(8):888-91.

9. Kamei K, Funabiki T, Ochiai M, Amano H, Kasahara M, Sakamoto T. Multifocal pancreatic serous cystadenoma with atypical cells and focal perineural invasion. Int J Pancreatol. 1991:10(2):161-72.

10. Okada T, Nonami T, Miwa T, Yamada F, Ando K, Tatematsu A, Sugie S, Kondo T. Hepatic metastasis of serous cystadenocarcinoma resected 4 years after operation of primary tumors-a case report. Nihon Shokakibyo Gakkai Zasshi. 1991;88(10):2719-23.

11. Yoshimi N, Sugie S, Tanaka T, Aijin W, Bunai Y, Tatematsu A, Okada T, Mori H. A rare case of serous cystadenocarcinoma of the pancreas. Cancer. 1992; 69(10):2449-53.

12. Ohta T, Nagakawa T, Itoh H, Fonseca L, Miyazaki I, Terada T. A case of serous cystadenoma of the pancreas with focal malignant changes. Int J Pancreatol. 1993;14(3):283-9.

13. Widmaier U, Mattfeldt T, Siech M, Beger HG. Serous cystadenocarcinoma of the pancreas. Int J Pancreatol. 1996;20(2):135-9.

14. Ishikawa T, Nakao A, Nomoto S, Hosono J, Harada A, Nonami T, Takagi H. Immunohistochemical and molecular biological studies of serous cystadenoma of the pancreas. Pancreas. 1998;16(1):40-4.

15. Eriguchi N, Aoyagi S, Nakayama T, Hara M, Miyazaki T, Kutami R, Jimi A. Serous cystadenocarcinoma of the pancreas with liver metastases. J Hepatobiliary Pancreat Surg. 1998;5(4):467-70.

16. Abe H, Kubota K, Mori M, Miki K, Minagawa M, Noie T, Kimura W, Makuuchi M. Serous cystadenoma of the pancreas with invasive growth: benign or malignant? Am J Gastroenterol. 1998;93(10):1963-6.

17. Wu CM, Fishman EK, Hruban RK, Schlott WD, Cameron JL. Serous cystic neoplasm involving the pancreas and liver: an unusual clinical entity. Abdom Imaging. 1999:24(1):75-7.

18. Strobel O, Z'Graggen K, Schmitz-Winnenthal FH, Friess H, Kappeler A, Zimmermann A, Uhl W, Buchler MW. Risk of malignancy in serous cystic neoplasms of the pancreas. Digestion. 2003;68(1):24-33.

19. Matsumoto T, Hirano S, Yada K, Shibata K, Sasaki A, Kamimura T, Ohta M, Kitano S, Kashima K. Malignant serous cystic neoplasm of the pancreas: report of a case and review of the literature. J Clin Gastroenterol. 2005;39(3): 253-6.

20. Shintaku M, Arimoto A, Sakita N. Serous cystadenocarcinoma of the pancreas. Pathol Int. 2005;55(7):436-9.

21. Friebe $V$, Keck T, Mattern D, Schmitt-Graeff A, Werner M, Mikami Y, Adam U, Hopt UT. Serous cystadenocarcinoma of the pancreas: management of a rare entity. Pancreas. 2005;31(2):182-7.

22. Gupta R, Dinda AK, Singh MK, Misra MC. Macrocystic serous cystadenocarcinoma of the pancreas: the first report of a new pattern of pancreatic carcinoma. J Clin Pathol. 2008:61(3):396-8.

23. Franko J, Cole K, Pezzi CM, Montone KT, Redmond J. Serous cystadenocarcinoma of the pancreas with metachronous hepatic metastasis. Am J Clin Oncol. 2008; 31(6):624-5

24. King JC, Ng TT, White SC, Cortina G, Reber HA, Hines OJ. Pancreatic serous cystadenocarcinoma: a case report and review of the literature. J Gastrointest Surg. 2009;13(10):1864-8.

25. Vadala S, Calderera G, Cinardi N, Manusia M, Li Volti G, Giannone G. Serous cystadenocarcinoma of the pancreas with portal thrombosis. Clin Ter. 2010; 161(2):149-52

26. Bano S, Upreti L, Puri SK, Chaudhary V, Sakuja P. Imaging of pancreatic serous cystadenocarcinoma. Jpn J Radiol. 2011;29(10):730-4.

27. Cho W, Cho YB, Jang KT, Kim HC, Yun SH, Lee WY, Chun HK. Pancreatic serous cystadenocarcinoma with invasive growth into the colon and spleen. J Korean Surg Soc. 2011;81(3):221-4.

28. Bramis K, Petrou A, Papalambros A, Manzelli A, Mantonakis E, Brennan N, Felekouras E. Serous cystadenocarcinoma of the pancreas: report of a case and management reflections. World J Surg Oncol. 2012;10:51.

29. Wasel BA, Keough $V$, Huang WY, Molinari M. Histological percutaneous diagnosis of stage IV microcystic serous cystadenocarcinoma of the pancreas. BMJ Case Rep. 2013. doi:10.1136/bcr-2012-007924.

30. Rathore MU, Arif A, Umair B. Serous cystadenocarcinoma of pancreas. J Coll Physicians Surg Pak. 2013;23(6):430-1. 
31. Kainuma O, Yamamoto H, Cho A, Arimitsu H, Yanagibashi H, Takiguchi N, Nabeya Y, Kawana H. Solid variant type of serous cystadenocarcinoma of the pancreas: A case report and review of the literature. Pancreatology. 2015:15(2):197-9.

32. Jais B, Rebours V, Malleo G, Salvia R, Fontana M, Maggino L, Bassi C, Manfredi R, Moran R, Lennon AM, et al. Serous cystic neoplasm of the pancreas: a multinational study of 2622 patients under the auspices of the International Association of Pancreatology and European Pancreatic Club (European Study Group on Cystic Tumors of the Pancreas). Gut. 2016;65(2):305-12.

33. Khashab MA, Shin EJ, Amateau S, Canto MI, Hruban RH, Fishman EK, Cameron JL, Edil BH, Wolfgang CL, Schulick RD, et al. Tumor size and location correlate with behavior of pancreatic serous cystic neoplasms. Am J Gastroenterol. 2011; 106(8):1521-6.

34. El-Hayek KM, Brown N, O'Rourke C, Falk G, Morris-Stiff G, Walsh RM. Rate of growth of pancreatic serous cystadenoma as an indication for resection. Surgery. 2013;154(4):794-800. discussion 800-792.

35. Robinson SM, Scott J, Oppong KW, White SA. What to do for the incidental pancreatic cystic lesion? Surg Oncol. 2014;23(3):117-25.

Submit your next manuscript to BioMed Central and we will help you at every step:

- We accept pre-submission inquiries

- Our selector tool helps you to find the most relevant journal

- We provide round the clock customer support

- Convenient online submission

- Thorough peer review

- Inclusion in PubMed and all major indexing services

- Maximum visibility for your research

Submit your manuscript at www.biomedcentral.com/submit
Biomed Central 